\title{
Reported incidence of occupational asthma in France, 1996-99: the ONAP programme
}

\author{
J Ameille, G Pauli, A Calastreng-Crinquand, D Vervloët, Y Iwatsubo, E Popin, \\ M C Bayeux-Dunglas, M C Kopferschmitt-Kubler, and the corresponding members of \\ the ONAP
}

Occup Environ Med 2003;60:136-141

See end of article for authors' affiliations

........................

Correspondence to: Dr J Ameille, Unité de pathologie professionnelle et de santé au travail, Hôpital Raymond Poincaré, 104 Bd. Raymond Poincaré, 92380 Garches,

France;

jacques.ameille@

rpc.ap-hop-paris.fr

Accepted 5 June 2002

\begin{abstract}
Aims: To estimate the general and specific incidence of occupational asthma in France in 1996-99; and to describe the distribution of cases by age, sex, suspected causal agents, and occupation. Methods: New cases of occupational asthma were collected by a national surveillance programme, based on voluntary reporting, named Observatoire National des Asthmes Professionnels (ONAP), involving a network of occupational and chest physicians. For each case, the reporting form included information on age, sex, location of workplace, occupation, suspected causal agent, and methods of diagnosis. Estimates of the working population, used to calculate incidence rates by age, sex, region, and occupation, were obtained from the Institut National de la Statistique et des Etudes Economiques (INSEE) and from the French Securite Sociale statistics.

Results: In 1996-99, 2178 cases of occupational asthma were reported to the ONAP, giving a mean annual rate of $24 /$ million. Rates in men were higher than rates in women $(27 /$ million versus 19 /million). The highest rate was observed in the 15-29 years age group (30/million). The most frequently incriminated agents were flour $(20.3 \%)$, isocyanates $(14.1 \%)$, latex $(7.2 \%)$, aldehyde $(5.9 \%)$, persulphate salts $(5.8 \%)$, and wood dusts $(3.7 \%)$. The highest risks of occupational asthma were found in bakers and pastry makers (683/million), car painters (326/million), hairdressers (308/million), and wood workers (218/million).

Conclusion: Despite likely underreporting, the number of cases of occupational asthma reported to the ONAP was approximately twice the number of compensated cases over the same period. The relevance of the programme is confirmed by the reproducibility of the results year after year, and its consistency with other surveillance programmes. The ONAP programme is useful for the identification of targets for primary prevention.
\end{abstract}

O ccupational asthma is one of the commonest occupational respiratory diseases in industrialised countries. ${ }^{1}$ It has been estimated that occupational factors are associated in about 1 in 10 cases of adult asthma. ${ }^{2}$ A recent population based follow up study, conducted in Finland, has even estimated that the fraction of asthma incidence attributable to work was $29 \%$ for men and $17 \%$ for women. ${ }^{3}$ Occupational asthma affects young and economically active patients and may result in serious respiratory disability, ${ }^{45}$ as well as severe socioeconomic consequences.

In France, information on the incidence of occupational asthma in the general working population or in specific occupations is mainly derived from compensation statistics available from the French Sécurité Sociale. Although useful, these data do not give a true representation of this public health problem, as, it has been shown that a significant number of workers with occupational asthma do not claim for compensation for fear of losing their job. Furthermore, published data suggest that occupational asthma is underdiagnosed and underreported in France. ${ }^{6}$ Accurate knowledge about the incidence of occupational asthma, the occupations concerned, and causative agents is necessary in order to implement effective preventive measures. In this field, surveillance programmes have proved to be very effective. Such programmes have been established in Finland, ${ }^{7}$ the United Kingdom, ${ }^{89}$ the USA, ${ }^{10}$ Sweden, ${ }^{11}$ Canada, ${ }^{12}$ and more recently Italy ${ }^{14}$ and South Africa. ${ }^{15}$

The French surveillance programme of occupational asthma, inspired by the SWORD scheme, was created in 1996 by the Société Française de Médecine du Travail (SFMT; French Society of Occupational Medicine) and the Société de
Pneumologie de Langue Française (SPLF; French Language Society of Pneumology). It was named Observatoire National des Asthmes Professionnels (ONAP). ${ }^{16}$ It was set up in order to develop a monitoring system for occupational asthma in France and to promote primary prevention based on a better knowledge of the incidence of occupational asthma by sex, age, and occupation, and a better knowledge of its causal agents.

In this article, we describe the surveillance programme and present the clinical characteristics, causal agents, and occupations identified in the first four years of the programme (1996-99), and the incidence rate by age, sex, region, and occupation.

\section{METHODS}

\section{Structure and set up of the reporting scheme}

Based on voluntary reporting, the ONAP involves a network of physicians, mainly occupational and chest physicians. It was started in January 1996. Information letters including the reporting form were sent by the SFMT and the SPLF to all members in France. Invitations to participate in the ONAP were also published in the Info Respiration SPLF journal.

Abbreviations: $\mathrm{Cl}$, confidence interval; $\mathrm{CNIL}$, Commission Nationale de I'Informatique et des Libertés; INSEE, Institut National de la Statistique et des Etudes Economiques; ONAP, Observatoire National des Asthmes Professionnels; RADS, reactive airways dysfunction syndrome; SFMT, Société Française de Médecine du Travail; SPLF, Société de Pneumologie de Langue Française 
Information on the goals and methods of the surveillance programme was also presented at several national and regional scientific meetings. Twenty five occupational medicine departments located in university hospitals, distributed all over the French territory, participated in ONAP. These departments are reference centres to which patients with suspected occupational diseases are referred by occupational physicians. Since 1997, the network has been expanded to include the physicians who grant statutory compensation for occupational diseases in the Ile-de-France region (Paris and surrounding areas). Furthermore, 59 corresponding members were appointed, to give information on the ONAP programme to occupational and chest physicians who are not members of the SFMT or SPLF, and to distribute and collect the reporting forms. As it has been shown that a successful surveillance programme requires a rapid feedback to the participants, the corresponding members were also responsible for circulating ONAP data, which are periodically updated, to the greatest number of physicians in France. The corresponding members were physicians working in occupational medicine departments, chest physicians working in university hospitals, and occupational physicians responsible for large occupational health services or regional occupational medicine societies.

\section{Individual reports}

The participating physicians were asked to report all new cases of asthma that they considered to be work related. For each case, the reporting form included information on the worker's age, sex, occupation at the time of diagnosis, type of industry, workplace location, and suspected agent. The reporting form also provided information on methods of diagnosis: measurement of bronchial non-specific responsiveness, specific IgE, specific skin prick tests, serial peak expiratory flow rates, serial flow-volume curves, specific nasal provocation tests, specific bronchial provocation tests. Three categories were proposed to the reporting physicians to characterise occupational asthma: typical asthma (with latency period), asthma-like syndrome (or atypical asthma), and reactive airways dysfunction syndrome (RADS; without latency period). The physician's opinion concerning the relation between work and asthma was requested and classified as certain, likely, and possible. To avoid duplicates, the first three letters of the surname, the first name, and the complete date of birth were provided. The information from each reporting form was entered into a computer database.

\section{Calculation of the incidence rates}

Data on the general working population and the number of workers in different occupations were obtained from the Institut National de la Statistique et des Etudes Economiques (INSEE) $)^{17}$ and from the French Sécurité Sociale statistics. They were used to estimate incidence rates by occupation, region, sex, and age. Because of the difficulties in obtaining precise information on the number of self employed workers, the calculations concerning the average annual reported incidence of occupational asthma by occupation were based only on salaried workers.

Confidence intervals (CIs) were calculated for rates by occupation, region, sex, and age, based on the Poisson distribution. $^{18}$

The ONAP programme has been approved by the French Commission Nationale de l'Informatique et des Libertés (CNIL), a commitee for computer privacy rights.

\section{RESULTS}

In 1996-99, a total of 2178 cases of occupational asthma were reported to the ONAP. Men constituted $63.1 \%$ of the cases $(\mathrm{n}=1375)$, women $36.9 \%(\mathrm{n}=803)$. Fifty five per cent of cases were reported by physicians from occupational medicine departments, $24 \%$ by chest physicians, $10 \%$ by occupational
Table 1 Average annual reported incidence of occupational asthma per million people employed, by age and sex, 1996-99

\begin{tabular}{lcrl}
\hline & Cases, $\mathbf{n}(\%)$ & $\begin{array}{l}\text { Working } \\
\text { population }\end{array}$ & $\begin{array}{l}\text { Incidence rate } \\
(95 \% \mathrm{CI})\end{array}$ \\
\hline Whole population & $2178(100.0)$ & 23055000 & $24(22$ to 25$)$ \\
$15-29$ y & $660(30.3)$ & 5600000 & $30(27$ to 32$)$ \\
$30-44$ y & $820(37.6)$ & 10200000 & $20(19$ to 22) \\
$45-59$ y & $593(27.2)$ & 5900000 & $25(23$ to 27) \\
Men & $1375(63.1)$ & 12708000 & $27(25$ to 29) \\
Women & $803(36.9)$ & 10347000 & $19(18$ to 21) \\
\hline
\end{tabular}

physicians, $7 \%$ by physicians granting statutory compensation for occupational diseases in the Ile-de-France region, 3\% by allergists, and $1 \%$ by other sources. Mean age was 37.3 (11.5) years and was similar for men (37.6 (11.8) years) and women (36.7 (11.0) years). A peak of frequency was observed in the $25-29$ and $30-34$ year age groups (16.4\% and $15.3 \%$ of cases, respectively).

Based on a working population in France of 23.06 million, the annual reporting rate was 24 per million for the whole population, 27 per million for men, and 19 per million for women (table 1). Notable differences were observed between regions (table 2 ).

Cases of occupational asthma were considered by the reporting physicians to be typical in $78.8 \%$ of cases, atypical in $15.7 \%$ of cases, and RADS in 5.5\%, of cases. Reported attempted methods of diagnosis were measurement of bronchial non-specific responsiveness (55.5\% of cases), skin tests $(48.3 \%)$, specific IgE $(47.0 \%)$, serial peak expiratory flow rates $(31.0 \%)$, serial flow volume curves $(25.7 \%)$, specific nasal provocation tests ( $13.0 \%)$, and specific bronchial provocation tests (11.4\%).

The relation between work and asthma was considered by the reporting physicians to be certain in $56.0 \%$ of cases, likely in $25.9 \%$ of cases, and possible in $18.2 \%$ of cases.

Among the various aetiologies reported in the four year observation period, biological agents represented $48.6 \%$ of suspected agents, chemical agents $42.8 \%$, and metals $2.5 \%$. Table 3 reports the most frequently suspected causal agents.

Table 2 Average annual reported incidence of occupational asthma per million people employed by region, 1996-99

\begin{tabular}{|c|c|c|c|}
\hline & $\begin{array}{l}\text { Cases } \\
\text { (n) }\end{array}$ & $\begin{array}{l}\text { Working } \\
\text { population }\end{array}$ & $\begin{array}{l}\text { Incidence rate } \\
(95 \% \mathrm{CI})\end{array}$ \\
\hline Alsace & 159 & 751000 & 53 (44 to 61) \\
\hline Aquitaine & 176 & 1115000 & 39 (33 to 45$)$ \\
\hline Auvergne & 15 & 510000 & 7 (4 to 12$)$ \\
\hline Bourgogne & 14 & 625000 & 4 (2 to 8$)$ \\
\hline Bretagne & 66 & 1123000 & 15 (11 to 18$)$ \\
\hline Centre & 77 & 978000 & 20 (15 to 24$)$ \\
\hline Champagne-Ardennes & 37 & 519000 & 18 (12 to 25$)$ \\
\hline Franche Comté & 57 & 449000 & 32 (24 to 41$)$ \\
\hline Ile-de-France & 786 & 4847000 & 41 (37 to 43$)$ \\
\hline Languedoc-Roussillon & 63 & 776000 & 20 (15 to 25$)$ \\
\hline Limousin & 8 & 272000 & $7(3$ to 15$)$ \\
\hline Lorraine & 55 & 888000 & 15 (9 to 23$)$ \\
\hline Midi-Pyrénées & 46 & 986000 & 12 (8 to 16$)$ \\
\hline Nord-Pas-de-Calais & 41 & 1373000 & $7(5$ to 10$)$ \\
\hline Basse Normandie & 76 & 547000 & 35 (27 to 43 ) \\
\hline Haute Normandie & 54 & 686000 & 20 (15 to 26$)$ \\
\hline Pays de la Loire & 78 & 1291000 & 15 (12 to 19$)$ \\
\hline Picardie & 20 & 717000 & $7(4$ to 11$)$ \\
\hline Poitou-Charentes & 20 & 621000 & 18 (13 to 24$)$ \\
\hline Provence Alpes-Côte d'Azur & 86 & 1589000 & 13 (10 to 17$)$ \\
\hline Rhône-Alpes & 194 & 2308000 & 24 (15 to 27$)$ \\
\hline
\end{tabular}


Table 3 Suspected causal agents of occupational asthma

\begin{tabular}{lcrr}
\hline Agent & $\begin{array}{l}\text { Whole population } \\
\mathrm{n}(\%)\end{array}$ & $\begin{array}{c}\text { Men } \\
\mathrm{n}(\%)\end{array}$ & $\begin{array}{l}\text { Women } \\
\mathrm{n}(\%)\end{array}$ \\
\hline Flour & $478(20.3)$ & $428(28.3)$ & $50(5.9)$ \\
Isocyanates & $333(14.1)$ & $278(18.4)$ & $55(6.5)$ \\
Latex & $169(7.2)$ & $18(1.2)$ & $151(17.8)$ \\
Aldehydes & $140(5.9)$ & $44(2.9)$ & $96(11.3)$ \\
Persulphate salts & $137(5.8)$ & $11(0.7)$ & $126(14.8)$ \\
Wood dusts & $87(3.7)$ & $78(5.0)$ & $9(1.1)$ \\
Mites & $72(3.1)$ & $41(2.7)$ & $31(3.7)$ \\
Alpha amylase & $67(2.8)$ & $65(4.3)$ & $2(0.2)$ \\
Resins and glues (isocyanates excluded) & $55(2.3)$ & $37(2.5)$ & $18(2.1)$ \\
Cereal dusts & $38(1.6)$ & $28(1.9)$ & $10(1.2)$ \\
Aliphatic amines & $35(1.5)$ & $19(1.3)$ & $16(1.9)$ \\
Chlorine and derived products & $35(1.5)$ & $17(1.1)$ & $18(2.1)$ \\
Quaternary ammonium & $29(1.2)$ & $3(0.2)$ & $26(3.1)$ \\
Laboratory animals & $27(1.1)$ & $15(1.0)$ & $12(1.4)$ \\
Mould & $24(1.0)$ & $14(0.9)$ & $10(1.2)$ \\
Farm animals & $20(0.8)$ & $7(0.5)$ & $13(1.5)$ \\
Welding fumes & $19(0.8)$ & $7(1.2)$ & $1(0.1)$ \\
Colophony & $18(0.9)$ & $10(0.5)$ & $11(1.3)$ \\
Pollens & $18(0.8)$ & $11(0.7)$ & $8(0.9)$ \\
Acid anhydrides & $17(0.7)$ & $244(16.1)$ & $6(0.7)$ \\
Other & $343(14.5)$ & $119(7.9)$ & $79(9.3)$ \\
Undetermined & $198(8.4)$ & $1512 *(100.0)$ & $847 *(100.0)$ \\
& & & 99 \\
Total & $2359 *(100.0)$ & & \\
\hline
\end{tabular}

*The number of suspected causal agents is higher than the number of cases of occupational asthma as multiple aetiologies were suspected in some cases.

Table 4 Main occupations in subjects with occupational asthma

\begin{tabular}{lcrr}
\hline Occupation & $\begin{array}{l}\text { Whole population } \\
\mathrm{n}(\%)\end{array}$ & $\begin{array}{l}\text { Men } \\
\mathrm{n}(\%)\end{array}$ & $\begin{array}{l}\text { Women } \\
\mathrm{n}(\%)\end{array}$ \\
\hline Bakers and pastry makers & $441(20.2)$ & $402(29.2)$ & $39(4.9)$ \\
Health workers & $227(10.4)$ & $15(1.1)$ & $212(26.4)$ \\
Painters (mainly spray painters) & $177(8.1)$ & $171(12.4)$ & $6(0.7)$ \\
Hairdressers & $149(6.8)$ & $15(1.1)$ & $134(16.7)$ \\
Wood workers & $112(5.1)$ & $104(7.6)$ & $8(1.0)$ \\
Farmers and stock breeders & $101(4.6)$ & $62(4.5)$ & $39(4.9)$ \\
Cleaners & $79(3.6)$ & $11(0.8)$ & $68(8.5)$ \\
Laboratory technicians & $42(1.9)$ & $15(1.1)$ & $27(3.4)$ \\
Welders & $35(1.6)$ & $33(2.4)$ & $2(0.2)$ \\
Textile workers & $34(1.6)$ & $21(1.5)$ & $13(1.6)$ \\
Other & $781(35.9)$ & $526(38.3)$ & $255(31.7)$ \\
Total & $2178(100.0)$ & $1375(100.0)$ & $803(100.0)$ \\
\hline
\end{tabular}

There were great differences in suspected causal agents between men and women. Flour and isocyanates were the two most commonly suspected causes of occupational asthma in men, while latex and persulphate salts were the most frequently suspected causes in women.

The greatest number of cases of occupational asthma was observed in bakers and pastry makers (table 4). The distribution of occupations according to gender also showed notable differences between men and women. Bakers and pastry makers were by far the most numerous in men $(29.2 \%)$, versus health workers in women $(26.4 \%)$. The highest incidence rates of occupational asthma were observed in bakers and pastry makers, and in car painters (table 5).

Trends observed over the four year observation period were the increasing number and proportion of cases of occupational asthma in women, the decreasing percentage of occupational asthma attributed to isocyanates, and the increasing number and percentage of occupational asthma in hairdressers (table 6).

Table 5 Average annual reported incidence of occupational asthma per million people employed, by occupation, 1996-99 (self employed workers excluded)

\begin{tabular}{lrcc}
\hline Occupation & $\mathrm{n}$ & Working population & Incidence rate $(95 \% \mathrm{Cl})$ \\
\hline Bakers and pastry makers & 410 & 150000 & 683 (617 to 749$)$ \\
Car painters & 111 & 85000 & 326 (265 to 387) \\
Hairdressers & 138 & 112000 & 308 (256 to 359) \\
Wood workers & 89 & 102000 & 218 (172 to 264) \\
Cleaners & 74 & 336000 & $55(42$ to 68) \\
Health workers & 213 & 1305000 & 41 (35 to 46) \\
\hline
\end{tabular}


Table 6 Variation of the distribution of cases of occupational asthma, by sex, suspected causal agents, and occupation over the observation period

\begin{tabular}{llccc}
\hline & $\begin{array}{l}1996 \\
\mathrm{n}(\%)\end{array}$ & $\begin{array}{l}1997 \\
\mathrm{n}(\%)\end{array}$ & $\begin{array}{l}1998 \\
\mathrm{n}(\%)\end{array}$ & $\begin{array}{l}1999 \\
\mathrm{n}(\%)\end{array}$ \\
\hline Total & $487(100.0)$ & $546(100.0)$ & $540(100.0)$ & $605(100.0)$ \\
Female & $152(31.2)$ & $195(35.7)$ & $204(37.8)$ & $252(44.7)$ \\
Agent & $107(20.4)$ & $127(22.6)$ & $127(21.2)$ & $117(17.6)$ \\
$\quad$ Flour & $85(16.1)$ & $89(15.8)$ & $72(12.1)$ & $87(13.1)$ \\
Isocyanates & $27(5.1)$ & $41(7.3)$ & $41(6.9)$ & $60(9.0)$ \\
Latex & $34(5.1)$ & $30(5.3)$ & $39(6.5)$ & $37(5.6)$ \\
Aldehydes & $26(5.0)$ & $23(4.1)$ & $40(6.7)$ & $48(7.2)$ \\
Persulphate salts & $23(4.4)$ & $21(3.7)$ & $17(2.8)$ & $26(3.9)$ \\
Wood dusts & $100(20.5)$ & $128(23.4)$ & $108(20.0)$ & $105(17.4)$ \\
Occupation & $39(8.0)$ & $60(11.0)$ & $64(11.9)$ & $64(10.6)$ \\
$\quad$ Bakers and pastry makers & $53(10.9)$ & $44(8.1)$ & $37(6.8)$ & $43(7.1)$ \\
Health workers & $27(5.5)$ & $27(4.9)$ & $43(8.0)$ & $52(8.6)$ \\
Painters & $27(5.5)$ & $27(4.9)$ & $27(4.9)$ & $31(5.1)$ \\
$\quad$ Hairdressers & & & \\
$\quad$ Wood workers & & &
\end{tabular}

\section{DISCUSSION}

In 1996-99, 2178 cases of occupational asthma were reported to the French ONAP surveillance programme, which represents a mean annual incidence of 24 cases par million workers. This number of reported cases was much (about twofold) higher than the number of cases of occupational asthma compensated over the same period in France.

However, the incidence rate of reported cases of occupational asthma in France, based on voluntary reporting, was much lower than the incidence rate in Finland, based on a national mandatory notification system, ${ }^{19}$ and in Sweden, based on self reported cases. ${ }^{11}$ It was slightly lower than the reported incidence in the United Kingdom, which is also based on voluntary reporting, ${ }^{20}$ and approximately the same as in Michigan and California. ${ }^{21} 22$

It is likely that our data considerably underestimate the true incidence of occupational asthma. An occupational cause may not be considered in all cases and, even if correctly diagnosed, may not be reported. Not every person with occupational asthma consults a doctor, and not all are referred to a chest physician or an occupational physician, as many patients with occupational asthma are examined by general practitioners or allergists who did not participate in the ONAP programme. This was particularly true for self employed workers whose jobs are often high risk jobs for occupational asthma. Lastly, many patients are reluctant to report occupational risk factors for fear of losing their job. ${ }^{6}$ The considerable differences in the regional incidence rates of occupational asthma, which cannot be explained by differences in the geographical distribution of high risk industries, probably reflect different levels of identification and reporting, and support the underreporting hypothesis.

On the other hand, the reported attempted methods of diagnosis of occupational asthma seldom included specific inhalation challenge tests. For a significant proportion of cases, clinical history was the only diagnostic tool. This supports the possibility of overreporting, as it has been shown that clinical history is sensitive but not specific for the diagnosis of occupational asthma. ${ }^{23}$ The question of diagnostic accuracy is a potential source of error. The choice not to specify reporting criteria or to validate the diagnosis of occupational asthma after reporting was made because of the absence of consensus on the diagnostic methods and definition of occupational asthma, and because of the importance of a simple procedure in order to maintain the physician's interest in the programme. ${ }^{13}$ A similar choice was previously adopted in most countries in which surveillances schemes of cases of occupational asthma have been implemented. ${ }^{7} 8101215$

Globally the French ONAP gave little relevant information on new causal agents, probably as a result of the tendency to attribute occupational asthma to well known agents in the case of concomitant exposure to substances with notorious sensitising effects. ${ }^{13}$

Despite these limitations, the reproducibility of our data, year after year, and their consistency with data of surveillance programmes in other countries make the ONAP relevant for the identification of privileged targets for primary prevention of occupational asthma.

Approximately two thirds of cases of occupational asthma reported to the ONAP were observed in men. The same sex ratio was observed in the United Kingdom, ${ }^{20} 24$ in Quebec province, Canada, ${ }^{13}$ and, to a lesser degree, in Sweden. ${ }^{11}$ In Finland, similar numbers of cases of occupational asthma were reported in men and women, as a result of the fact that a high proportion of cases occurred in farmers, in whom the sex ratio is close to $1 .{ }^{25}$

Analysis of cases reported in the United Kingdom, ${ }^{24}$ Sweden, ${ }^{11}$ and Quebec province, ${ }^{13}$ has shown an apparent increase in the incidence rate of occupational asthma in both sexes with age. These differences were not explained by differences in occupation by age. Two explanations have been proposed for these findings ${ }^{91121}$ : first, an increased susceptibility with age because of previous or longer occupational exposures, or personal habits such as smoking; second, socioeconomic reasons - that is, older workers may wish to stay in jobs despite their symptoms and seek medical care at a later stage, whereas younger people are more likely to remove themselves from exposure without seeking medical advice. Our findings, which showed the highest annual reporting rate in the 15-29 year age group, do not support an increased susceptibility with age. A large majority of cases were reported to the ONAP by occupational physicians or by occupational medicine departments to which patients are mostly referred by occupational physicians. The occupational physicians network in France is very dense (more than 6000 occupational physicians), and most workers (self employed workers excluded) are examined annually so that the diagnosis of occupational asthma might be made earlier than in other countries.

The highest incidence rates of occupational asthma in France were observed in bakers and pastry makers, and in car painters. High rates in these occupations have also been found in the United Kingdom, ${ }^{24}$ Sweden, ${ }^{11}$ and Finland. ${ }^{25}$ According to the ONAP data, flour and isocyanates were the two most frequent causal agents in France. Flour was also the leading cause in Finland. ${ }^{25}$ The proportion of cases of occupational asthma related to the inhalation of flour in the workplace was lower in the United Kingdom, ${ }^{9}$ and in Quebec province, ${ }^{13}$ probably because bakers and pastry makers are less numerous in these countries. As observed in France, isocyanates were 
also a leading cause of occupational asthma in the United Kingdom, ${ }^{8}$ in Quebec province, ${ }^{13}$ and in the state of Michigan, USA, ${ }^{26}$ but not in Finland. ${ }^{19}$ The data from the French ONAP also showed high incidences of occupational asthma among less recognised occupations, such as hairdressers and cleaners. According to the ONAP data, hairdressing represented the fourth most frequent occupation (both sexes) and the second most frequent occupation in women, among subjects with occupational asthma. The annual incidence rate in hairdressers was 308 per million. A similar rate has only been found in Finland. ${ }^{25}$ In Sweden, the reported rate of occupational asthma in hairdressers was 129 per million. ${ }^{11}$ In the United Kingdom the rate was 24 per million for the 1992-97 period. ${ }^{20}$ In the west Midlands region, in the United Kingdom (SHIELD scheme), in the USA (SENSOR programme), and in Quebec province (PROPULSE), hairdressers were not even listed in the high risk occupations for asthma. ${ }^{96} 13$

Most of our cases were attributed to the inhalation of persulphate salts, which are widely used as constituents of hair bleaches. Persulphate salts have been known to cause asthma for several decades. In 1986, an investigation carried out in a hairdressing salon in London with 23 staff members found four cases of occupational asthma caused by persulphate salts contained in hair bleaches. ${ }^{27}$ Hairdressers may also be exposed to several other substances capable of producing respiratory symptoms, such as amines in hair dyes, henna, and lycopod powder. Our findings are consistent with the results of a retrospective cohort study using a self administered questionnaire to assess the risk for female hairdressers to develop asthma in Finland. ${ }^{28}$ The relative risk of developing asthma during the 15 year observation period was 1.7 (95\% CI: 1.1 to 2.5) among hairdressers, compared with referents. In a population based study in Spain, ${ }^{29}$ an increased risk of occupational asthma was also observed in hairdressers (OR 1.94; $95 \%$ CI 0.86 to 4.39 ), where asthma was defined by the presence of wheezing or whistling in the chest during the previous 12 months.

According to the ONAP data, cleaning jobs were the third most frequent occupation in women with occupational asthma. A high incidence rate of occupational asthma was also found in Finland, ${ }^{25}$ and Sweden, ${ }^{30}$ in female cleaners, but not in the United Kingdom. ${ }^{20}{ }^{24}$ In a large population based study, comprising 15637 people aged 20-44 years, randomly selected from the general population of 26 areas in 12 industrialised countries, ${ }^{31}$ a high risk of asthma defined as bronchial hyperresponsiveness and reported asthma, symptoms, or medication, was shown in cleaners (OR 1.97; 95\% CI 1.33 to 2.92). The excess risk for cleaners was observed in nearly all countries in this study. Furthermore, the group of cleaners was the largest of the 16 occupational groups to show an increased risk of more than $30 \%$. In the states of California, Massachussets, Michigan, and New Jersey, participating in the SENSOR programme, cleaning materials represented $4.7 \%$ of the suspected agents associated with new onset cases of work related asthma. ${ }^{32}$ These cleaning materials can contain respiratory irritants such as chlorine and ammonia, or sensitisers such as aldehydes or benzalkonium chloride. Cleaners are also exposed to indoor allergens such as mites, and to latex allergens via latex gloves. In our study, mites and latex were the most frequent suspected agents in cleaners with occupational asthma, in accordance with the findings of the SWORD study, which showed that cleaners represented one of the occupations with the highest rate of occupational asthma attributed to latex. ${ }^{33}$ It has also been suggested that the increased risk of asthma in cleaners might be explained by the use of sprays and other products in kitchen cleaning and furniture polishing. ${ }^{34}$

\section{Conclusion}

Occupational asthma is a good example of a potentially preventable health problem. Despite a likely underreporting of

\section{Main messages}

- Occupational asthma is a common disease in France.

- Flour and isocyanates are the two most frequent causal agents of occupational asthma in France.

- The highest incidence of occupational asthma in France occurs in bakers, car painters, and hairdresssers.

\section{Policy implications}

- Primary preventive actions need to be carried out to prevent occupational asthma, especially in bakeries, hairdressing salons, and car body repair shops.

cases of occupational asthma, the French ONAP has proved to be a useful surveillance programme. It has elucidated the respective importance of risks in the workplace and identified privileged targets for primary prevention.

\section{ACKNOWLEDGEMENTS}

This programme was supported by grants from the French Ministère de l'emploi et de la solidarité, the Caisse Nationale d'Assurance Maladie des Travailleurs salariés, and the Comité National des Maladies Respiratoires. It was also supported by Glaxo Wellcome. We express our gratitude to all physicians who took part in the programme.

\section{....................}

Authors' affiliations

J Ameille, A Calastreng-Crinquand, Y Iwatsubo,

M C Bayeux-Dunglas, Institut Interuniversitaire de Médecine du Travail de Paris lle-de-France, 45 Rue des Saints-Pères, 75270 Paris Cedex 06,

France

G Pauli, D Vervloët, E Popin, M C Kopferschmitt-Kubler, Société de Pneumolgie de Langue Française, 66 Boulevard Saint Michel, 75006 Paris, France

Corresponding members of the ONAP: G Arnaud, A Bergeret, $M$ Blaumeiser, $F$ de Blay, L Boitel, C Bonnin, P Brochard, J Brun C Cabal, B Cador, D Caillaud, A Cantineau, J Chazenfus, D Choudat,

F Conso, S Costes, M Couot, J P Curtes, J C Dalphin, D Danaud, Ph Danjou, B Delemotte, F Deschamps, J D Dewitte, A Didier,

H Dhivert-Donnadieu, C Doutrellot-Philippon, F Dufresne-Benetti,

D Dumont, D Dupas, D Faucon, J L Fumery, D Gabrillargues, R Garnier,

P Godard, F Grudzien, J M Hémery, B Javelaud, G Lasfargues, B Leleu,

M Letourneux, B Libert, J Loriot, F Martin, M P Michel, C Nisse, C Paris,

J C Pairon, D Penneau-Fontbonne, A Perdrix, G Petiet,

P Pommier de Santi, H Robin, M Saadiian, H J Smolik, J M Soulat,

C Tarin, D Terracol, C Tessier-Cotte, J M Tunon de Lara

\section{REFERENCES}

1 Chan-Yeung M, Malo JL. Occupational asthma. N Engl J Med 1995:333:107-12

2 Blanc PD, Torén K. How much asthma can be attributed to occupational factors? Am J Med 1999; 107:580-7

3 Karjalainen A, Kurppa K, Martikainen R, et al. Work is related to a substantial portion of adult-onset asthma incidence in the Finnish population. Am J Respir Crit Care Med 2001 164:565-8.

4 Chan-Yeung M, Malo JL. Natural history of occupational asthma. In: Bernstein IL, Chang-Yeung M, Malo JL, Bernstein DI, eds. Asthma in the workplace. New York: Marcel Decker, 1999: 129-44.

5 Pauli G, Kopferschmitt-kubler MC. Pronostic médical. In: Bessot J, Pauli G, eds. L'asthme professionnel. Paris: Margaux Orange, 1999:523-36.

6 Ameille J, Pairon JC, Bayeux MC, et al. Consequences of occupational asthma on employment and financial status: a follow-up study. Eur Respir J 1997; 10:55-8.

7 Keskinen H, Alanko K, Saarinen L. Occupational asthma in Finland. Clin Allergy 1978:8:569-79.

8 Meredith SK, Taylor VM, McDonald JC. Occupational respiratory disease in the United Kingdom 1989: a report of the British Thoracic Society and the Society of Occupational Medicine by the SWORD project group. BrJ Ind Med 1991;48:292-8.

9 Gannon PFG, Burge PS. The SHIELD scheme in the West Midlands region, United Kingdom. Br J Ind Med 1993;50:791-6.

10 Matte TD, Hoffman RE, Rosenman KD, et al. Surveillance of occupational asthma under the SENSOR model. Chest 1990;98(suppl): 173S-8S.

11 Torén K. Self-reported rate of occupational asthma in Sweden 1990-2. Occup Environ Med 1996;53:757-61 
12 Contreras GR, Rousseau R, Chang-Yeung M. Occupational respiratory diseases in British Columbia, Canada in 1991. Occup Environ Med 1994;51:710-12

13 Provencher S, Labrèche FP, De Guire L. Physician-based surveillance system for occupational respiratory diseases: the experience of PROPULSE, Quebec, Canada. Occup Environ Med 1997:54:272-6.

14 Bena A, d'Errico A, Mirabelli D, gruppo di allergologia del programmo PRIOR. Active epidemiologic surveillance of work-related asthma in the PRIOR programme. Med Lav 1999;40:556-71.

15 Hnizdo E, Esterhuizen M, Rees D, et al. Occupational asthma as identified by the surveillance of work-related and occupational respiratory diseases programme in South Africa. Clin Exp Allergy 2001;31:32-9.

16 Kopferschmitt-Kubler MC, Ameille J, Popin E, et al. Occupational asthma in France (a 1-yr report of the Observatoire National des Asthmes Professionnels project). Eur Respir J 2002; 19:84-9.

17 INSEE. Annuaire statistique de la France. Paris: INSEE, 2000.

18 Gardner MJ. Tables for the calculation of confidence intervals. In: Gardner M, Altman DG, eds. Statistics with confidence-confidence intervals and statistical guidelines. London: BM Publications, 1989:116-18.

19 Meredith S, Nordman H. Occupational asthma: measures of frequency from four countries. Thorax 1996;51:435-40.

20 McDonald JC, Keynes HL, Meredith SK. Reported incidence of occupational asthma in the United Kingdom, 1989-1997. Occup Environ Med 2000:57:823-9.

21 Henneberger PK, Kreiss K, Rosenman KD, et al. An evaluation of the incidence of work-related asthma in the United-States. Int J Occup Environ Health 1999;5:1-8.

22 Reinish F, Harrison RJ, Cussler S, et al. Physician reports of work-related asthma in California, 1993-1996. Am J Ind Med 2001:39:72-83.

23 Malo JL, Ghezzo H, L'Archevêque J, et al. Is the clinical history a satisfactory means of diagnosis of occupational asthma? Am Rev Respir Dis $1991 ; 143: 528-32$
24 Meredith S. Reported incidence of occupational asthma in the United Kingdom, 1989-1990. J Epidemiol Community Health 1993;47:459-63

25 Karjalainen A, Kurppa K, Virtanen S, et al. Incidence of occupational asthma by occupation and industry in Finland. Am J Ind Med 2000;37:451-8.

26 Rosenman KD, Reilly M, Kolinowski DJ. A state-based surveillance system for work-related asthma. J Occup Environ Med 1997:39:415-25.

27 Blainey AD, Ollier S, Cundell D, et al. Occupational asthma in a hairdressing salon. Thorax 1986;41:42-50.

28 Leino T, Tammilehto L, Paakulainen $\mathrm{H}$, et al. Occurrence of asthma and chronic bronchitis among female haidressers. J Occup Environ Med 1997:39:534-9.

29 Kogevinas M, Antó JM, Soriano JB, et al. The risk of asthma attributable to occupational exposures. A population-based study in Spain. Am J Respir Crit Care Med 1996;154:137-43.

30 Torén $\mathbf{K}$, Balder $\mathrm{B}$, Brisman J, et al. The risk of asthma in relation to occupational exposures: a case-control study from a Swedish city. Eur Respir J 1999;13:496-501.

31 Kogevinas M, Antó JM, Sunyer J, et al. Occupational asthma in Europe and other industrialised areas: a population-based study. Lancet 1999;353:1750-4.

32 Romero Jajosky RA, Harrison R, Reinisch F, et al. Surveillance of work-related asthma in selected US states using surveillance guidelines for state health departments. California, Massachussets, Michigan, and New Jersey, 1993-1995. MMWR 1999;48:1-20.

33 Ross DJ, Keynes HL, McDonald JC. SWORD'97: surveillance of work-related and occupational respiratory disease in the UK. Occup Med 1998;48:481-5

34 Zock JP, Kogenivas M, Sunyer J, et al. Asthma risk, cleaning activities and use of specific cleaning products among Spanish indoor cleaners. Scand J Work Environ Health 2001;27:76-81.

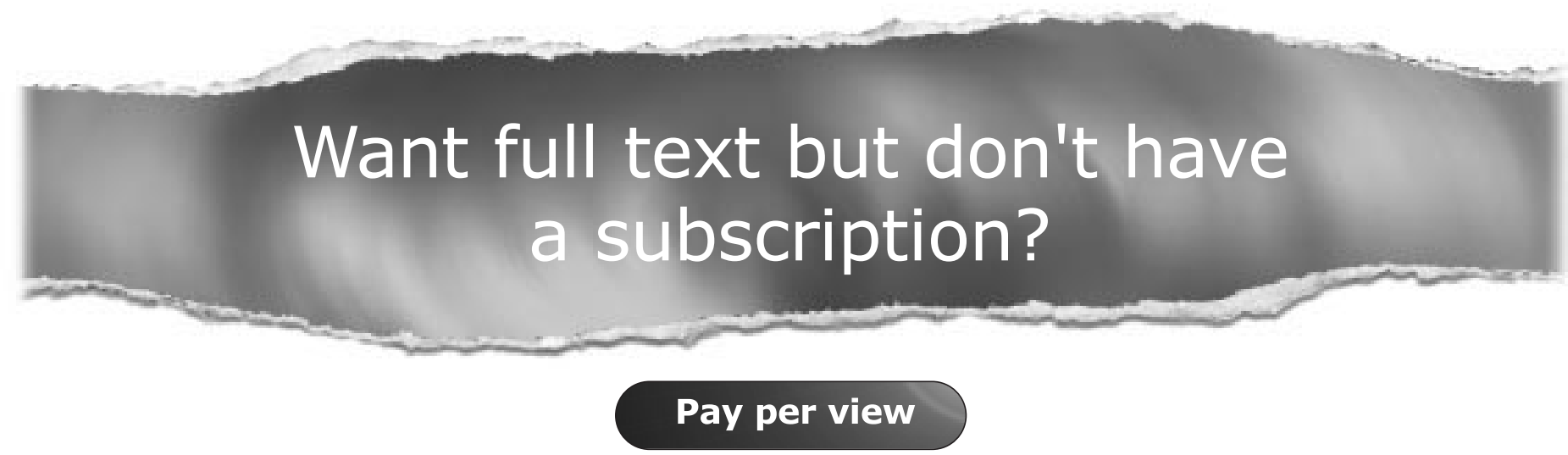

For just $\$ 8$ you can purchase the full text of individual articles using our secure online ordering service. You will have access to the full text of the relevant article for 48 hours during which time you may download and print the pdf file for personal use.

www.occenvmed.com 